\title{
Płodność działalności planowanej ${ }^{1}$
}

\author{
Michael E. Bratman (Stanford University, Kalifornia)
}

\section{Trzy zdolności praktyczne}

Jako normalne dorosłe podmioty działające, dysponujemy znaczącym triem zdolności praktycznych. Po pierwsze, jesteśmy zdolni do działania w czasie w sposób, który zakłada ważne formy inter-temporalnej intencjonalnej organizacji i koordynacji. Pomyśl o warzywach rosnących w twoim ogrodzie. Musisz przygotować glebę, posadzić rośliny, nawodnić, uprawić i zebrać owoce. Aktywności te odbywają się w czasie i każdą z nich przenika zrozumienie (i zobowiązanie podmiotu do) większego, czasowo rozciągniętego wachlarza aktywności. Jest to przykład intencjonalnej działalności rozciągniętej w czasie ${ }^{2}$.

Po drugie, mamy zdolność współdziałania z innymi w sposób, który znacząco wykracza poza standardowe formy strategicznej interakcji. Pomyśl o kwartecie fortepianowym. Nie chodzi tylko o to, że każdy z członków kwartetu działa w sposób, który najlepiej promuje to, co dany podmiot chce - na podstawie wiedzy o tym, co inne podmioty działające robią w tym kwartecie i tego, że myśli i działania innych podmiotów mają paralelną strukturę. Chodzi raczej o to, że każdy widzi siebie i swoich partnerów jako działających razem w taki sposób, który zakłada szczególne formy zaangażowania i reakcji na wspólną aktywność, jak również - na udział każdej osoby w tej wspólnej aktywności. Jest to przykład kolektywnej aktywności intencjonalnej ${ }^{3}$.

Po trzecie, mamy zdolność samorządności (self-governance). Gdy się jednak nad tym zastanowić, może się to wydawać tajemnicze. Obraz czyjegoś Ja jako opuszczającego strumień świadomości i przesądzającego o tej kwestii jest głęboko problematyczny - nawet jeśli faktycznie odzwierciedla pewne aspekty naszego doświadczenia naszej działalności. Jednak w przypadku braku takiego homunculusa - cóż znaczy dla samego podmiotu, że sobą rządzi?

Teoria ludzkiej działalności powinna zawierać pojęcie tego tria zdolności: zdolności do działalności rozciągniętej w czasie (temporally extended), działalności kolektywnej (shared) i intencjonalnej działalności jako

\footnotetext{
1 Tekst ten w dużej mierze jest modyfikacją odczytu inauguracyjnego na 84. Corocznym Zjeździe Zachodniej Dywizji Amerykańskiego Towarzystwa Filozoficznego, cf. (Bratman, 2010) - przyp. tłum.

2 Podobną idę można znaleźć w (Ferrero 2009).

$3 \mathrm{~W}$ rzeczy samej, to jest to, co nazywam kolektywną aktywnością kooperacyjną. Zob. (Bratman 1999a). Tu jednak będę pracował z nieco szerszym pojęciem kolektywnej aktywności intencjonalnej.
} 
samorządności (self-governed intentional agency). W każdym przypadku mamy trzy wzajemnie powiązane sprawy. Po pierwsze, chcemy wiedzieć, jakie pojęcia najlepiej wspierają nasze teoretyczne rozumienie tych fenomenów. Po drugie, chcemy zrozumieć, jak to jest, że urzeczywistniamy te zdolności. Po trzecie, chcemy zrozumieć szczególne aspekty normatywne tych zdolności. Nasze zainteresowania mają więc charakter pojęciowy, metafizyczny i normatywny.

Moją odpowiedzią na te kwestie ma być próba zrozumienia tych trzech zdolności praktycznych poprzez odwołanie do wspólnej, zasadniczej zdolności do indywidualnej działalności planowanej. Ta zasadnicza zdolność planowania sama wystarcza do bycia zdolnym do rozciągniętej w czasie działalności intencjonalnej. Co więcej, gdy ją odpowiednio uzupełnimy, ta zasadnicza zdolność wystarcza do bycia zdolnym do kolektywnej działalności intencjonalnej i działalności jako samorządności. Te środki uzupełniające stanowią w dużej mierze ciągłość względem środków, którymi dysponujemy w ramach naszej teorii indywidualnej działalności planowanej. W ten sposób tworzymy pomost między środkami pojęciowymi, metafizycznymi i normatywnymi dla modelu naszej indywidualnej działalności planowanej a pojęciowymi, metafizycznymi i normatywnymi środkami adekwatnymi dla modelu każdej z tria zdolności praktycznych, które wymieniliśmy. Artykułujemy przeto struktury działalności planowanej, które wystarczają dla zasadniczych przypadków działalności rozciągniętej w czasie, działalności kolektywnej i działalności jako intencjonalnej samorządności. Hipoteza płodności działalności planowanej jest taka, że owo trio ludzkich zdolności praktycznych - a być może innych również ${ }^{4}$ jest w ten sposób ugruntowane w naszej zdolności do działalności planowanej5.

\section{Myślenie praktyczne i czas}

Nie wszystkie podmioty działające są podmiotami planującymi. Mogą istnieć podmioty zorientowane na cel, które nie strukturyzują swoich myśli i działania w czasie poprzez planowanie. Psy i bardzo młode dzieci są tu przykładami. Takie podmioty angażują się w aktywność zorientowaną na cel, w której ich zachowanie śledzi cel - powiedzmy, otrzymanie łyka wody. Może to zakładać złożoną plastyczność reagowania - spragniony pies może odpowiednio zareagować na twoje podsunięcie miski $\mathrm{z}$ wodą. Zdaje się jednak nieprawdopodobne, że pies, czy 15-miesięczny człowiek, określa plany dla

\footnotetext{
${ }^{4}$ Allan Gibbard rozpatruje naszą zdolność do działalności planowanej jako podstawę myślenia normatywnego (Gibbard 2003). Scott Shapiro traktuje zaś prawo jako ugruntowane w naszych zdolnościach planowania. (Shapiro 2011). Zarówno Gibbard jak i Shapiro mierzą w ten sposób w rozszerzenie płodności działalności planowanej.

5 (Bratman 2010). Kluczowy jest tu wymóg zagwarantowania warunków wystarczających dla zasadniczych przypadków tych form ludzkiej działalności. Hipoteza płodności działalności pozostawia otwartą możliwość wielu takich warunków wystarczających.
} 
okresu rozciągniętego $\mathrm{w}$ czasie i myśli o swoim zachowaniu i organizuje je w czasie pod kątem tych planów. Oczywiście, czy pies lub młode dziecko organizuje (lub nie) swoje myśli i działania w ten planowo określony (planinfused) sposób, jest kwestią empiryczną; być może badania psychologiczne w tej kwestii nas zaskoczą. Jednak zasadniczą sprawą jest tutaj rozróżnienie, z jednej strony, rozciągniętej w czasie działalności lokalnie zorientowanej na cel i, z drugiej strony, diachronicznej działalności kierowanej przez plan ${ }^{6}$.

Gdy planujemy, poważnie traktujemy to, co mamy zrobić później, tak samo, jak to, co zrobić teraz. Ale dlaczego przejmować się tym, co zrobić później? Dlaczego po prostu nie przejmować się tym, co zrobić teraz i przerzucić mosty dopiero wtedy, gdy będziesz miał je przekroczyć? Zdroworozsądkowa odpowiedź jest taka, że powinniśmy wiedzieć o tym, co zrobić później, po to, by wiedzieć o tym, co zrobić teraz i skoordynować nasze aktywności wcześniejsze z późniejszymi. Kiedy postanowię wybrać się do Nowego Orleanu w przyszłym miesiącu, jest jasne, że wcześniej muszę zdobyć bilet lotniczy. Z drugiej strony, jeśli po prostu teraz zapytam „czy powinienem teraz postarać się o bilet na przyszły miesiąc do Nowego Orleanu?", normalnie nie mogę odpowiednio odpowiedzieć na to pytanie bez jednoczesnego ustalenia, czy tam wtedy lecieć. W interesie inter-temporalnej koordynacji częstokroć muszę ustalić teraz to, co zrobię później, a więc planować odpowiednio to co, zrobić teraz. Ustalając teraz, że wybiorę się do Nowego Orleanu w przyszłym miesiącu, zaczynam przechodzić w stan planowania (plan state), który jest zorientowany na przyszłość. Rozumiemy, czym jest ów stan planowania, wyjaśniając jego rolę w racjonalnej dynamice działalności planowanej.

Ten nacisk w kierunku planowania zorientowanego na przyszłość jest szczególnie wyraźny w przypadku takich podmiotów o ograniczonych zasobach, jak my (Por. Simon 1983). Często musimy ustalić teraz, co zrobić później - po części dlatego, że nie możemy rozsądnie wierzyć, że kiedy późniejszy czas nadejdzie, będziemy w stanie - w obliczu danych nacisków do działania - skutecznie radzić sobie z wszystkimi trudnościami i podjąć od razu odpowiednią decyzję.

Rozwijając ideę inter-temporalnej koordynującej roli planowania, musimy również oddać sprawiedliwość dwóm kolejnym, zdroworozsądkowym ideom. Pierwsza jest idea wyboru spośród alternatywnych opcji, z których każda byłaby odpowiednia, jest to jeden $\mathrm{z}$ aspektów - jak moglibyśmy powiedzieć - idei "woli”7. Wyborów takich dokonujemy ciągle, od różnych dróg do danego celu począwszy, przez różne kariery, skończywszy na wyborze dokonanym przez młodego człowieka u Sartre’a pomiędzy pomocą dla swojej

${ }^{6}$ Jeśli chodzi o ideę działalności planowanej jako gatunku działalności, zob. moje wykorzystanie strategii „konstrukcji istoty” (creature construction) (Grice 1974-75) w (Bratman 2007f).

7 Drugim aspektem jest idea woli mocy. Zob. (Holton 2009). Tutaj również, jak argumentuje Holton, teoria planowania może być użyteczna. 
matki i walką na rzecz Wolnej Francji (Sartre 1975, 354-356). Niemniej jednak, wybory te, niedookreślone przez pogląd podmiotu działania na własne powody do działania ${ }^{8}$, określają odpowiednie kwestie praktyczne i grają zasadniczą, określoną przyszłościowo rolę $\mathrm{w}$ inter-temporalnej koordynacji działania. Zdolność dokonywania wyborów i określania takich kwestii wydaje się podstawową cechą ludzkiej działalności - taką, która pomaga wyjaśnić, dlaczego nie cierpimy nieustannie na syndrom osiołka Buridana. Jest to zdolność wykonania przejścia ze stanu niezdecydowania pomiędzy kilkoma alternatywami, z których każda wydaje się sensowna, do stanu bycia zdecydowanym na jedną szczególną spośród tych alternatyw. Rozumiemy ten stan końcowy w dużej części w terminach jego roli dla działalności planowanej: bycie zdecydowanym na daną opcję to - również blisko z nim spokrewnione ${ }^{9}$ bycie $\mathrm{w}$ stanie planowania, gdzie, raz jeszcze, rozumiemy, czym jest stan planowania, wyjaśniając jego role $\mathrm{w}$ racjonalnej dynamice działalności planowanej. W ten sposób opieramy się nazbyt prostej koncepcji woli $\mathrm{w}$ segmencie czasu (time-slice ${ }^{10}$ conception), osadzając nasze ujęcie woli w ramach większego modelu diachronicznej działalności planowanej.

Po drugie, mamy ideę intencji. Musimy tu uważać i rozróżnić formy przysłówkowe - jak w przypadku: "zrobił to intencjonalnie" - od czasownika "intendować/zamierzać"11. Zasadnicza idea, o którą tu chodzi, dotyczy tego

${ }^{8} \mathrm{~W}$ oryg. reasons; tłumaczę ten termin na dwa sposoby, w zależności od stylistycznej adekwatności, jaką sugeruje poprawna polszczyzna: albo jako racje albo - powody. Jest to zabieg nie tylko mający spełniać standardy praktyki filologicznej. Takie ujęcie sprawy oznacza też implicytne zajęcie pewnego stanowiska w toczącej się współcześnie niezwykle żywej debacie na temat racji do działania, nie ma tu jednak miejsca na pełniejsze przybliżenie tej kwestii; poprzestanę na stwierdzeniu, iż ciągle żywy w tej debacie spór psychologizmu racji (tłumaczącego racje jako złożenie pragnień z przekonaniami) z antypsychologizmem, jest pozbawiony podstaw, bowiem zagadnienie racji do działania - m.in. ze względu na specyfikę języków etnicznych, która owocuje istnieniem powodów obok racji - nie konstytuuje teorii w sensie, o który toczy się ten spór - przyp. tłum.

9 Taka kwalifikacja jest potrzebna, by uwzględnić złożoną relację między wyborem I intencją, którą omawiam w (Bratman 1987, rozdz. 10).

10 Bratman posługuje się tu stosunkowo popularnym zwrotem $\mathrm{w}$ jęz. angielskim (zadomowionym $\mathrm{w}$ kinematografii czy nawet $\mathrm{w}$ informatyce), który nie ma odpowiednio bogatego semantycznie odpowiednika w języku polskim - przyp. tłum.

11 Od tłumacza: Po bojach toczonych z - mówiąc językiem Kotarbińskiego, własnym sumieniem semantycznym - zdecydowałem się w całym przekładzie zachować utarte $\mathrm{w}$ języku polskim tłumaczenie intention jako intencja. Intencja ma w języku polskim dość wyraźne konotacje moralne, których, etymologicznie rzecz biorąc, mieć nie powinna. Filologicznie lepszy wydaje mi się zamiar, intencja wygrywa jednak z powodów filozoficznych. Z intencją wiąże się problem tłumaczenia to intend jako intendować. Choć ten polski wariant jest odpychający, to jednak występuje czasami w tekstach naukowych i, co ważniejsze, zawiera tak istotny komponent etymologiczny, do którego Bratman się odwołuje. Zdecydowałem się oddać ten czasownik na dwa sposoby, w zależności od potrzeb zręczności językowej (tam, gdzie Bratman nawiązuje do etymologii, intend tłumaczę jako intendować/zamierzać - jest to zresztą 
drugiego oraz korespondującego z nim fenomenu intencji; możemy tu dopuścić mniej lub bardziej złożoną relację między robieniem $X$ intencjonalnie oraz intendowaniem/zamierzaniem zrobić $X .12$ Zasadnicza myśl jest taka, że zamierzać coś zrobić, to znajdować się w stanie planowania, gdzie - ponownie - rozumiemy, czym jest stan planowania poprzez wyjaśnienie jego roli w racjonalnej dynamice działalności planowanej. Intencja prowadzi do działania w sposób, który normalnie zakłada diachroniczne struktury planowania.

Zatem - model racjonalnej dynamiki i związanych $\mathrm{z}$ nim intertemporalnych ról koordynujących działalnością planowaną byłby również teorią woli i teorią intencji13. To stanowi obietnicę głębszego zrozumienia nastawionej na przyszłość natury woli oraz złożonych, diachronicznych i wzajemnych powiązań między naszymi myślami i naszym działaniem. Hipoteza płodności działalności planowanej jest taka, że ów model planowania rzuca światło na trio zdolności podmiotowości praktycznej, od którego zaczęliśmy.

\section{Działalność planowana}

Pozwolę sobie teraz naszkicować model naszej indywidualnej działalności planowanej, który omówiłem w innym miejscu (Zob. Bratman 1987). Zaczynamy od planu działania. Plan takowy określa sposoby działania teraz i w przyszłości. Wiąże sposoby działania z naszymi przekonaniami na temat świata w mniej lub bardziej konsekwentną i spójną sieć, jednakże sieć taka normalnie będzie i niepełna, jeśli chodzi o to, co istotne oraz warunkowa, jeśli chodzi o strukturę. Planować coś zrobić, to być odpowiednio zobowiązanym

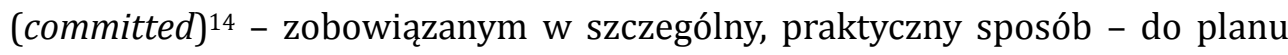

bratmanowska metoda, por. jego intending/planning). W innych wypadkach pozostaje zamierzać - przyp. tłum.

$12 \mathrm{~W}$ tym miejscu argumentowałem przeciw „Poglądowi Prostemu”, zgodnie z którym jest zawsze prawdą, że w intencjonalnym robieniu $A$ zamierzamy zrobić $A$. (Bratman 1987, rozdz. 8). W tej dyskusji rozważałem również „pogląd pojedynczego fenomenu”, zgodnie z którym, gdy intencjonalnie robimy $A$, tym samym coś zamierzamy, choć prawdopodobnie w szczególności nie $A$. Stwierdziłem, że coś w tym rodzaju będzie w „ogromnej większości przypadków” prawdą, ale zostawiłem otwartą kwestię, czy mogą istnieć marginalne przypadki, w których działamy intencjonalnie i mimo wszystko o intencji - stanie planowania - nie ma mowy. (s. 126-7). Tym, co tu istotne, jest wbudowana w teorię planowania hipoteza, że przypadki działania intencjonalnego, w których te dane stany planowania są zupełnie nieobecne - jeśli miałyby w ogóle wchodzić w grę - są teoretycznie marginalne dla zrozumienia naszej działalności ludzi dorosłych. Jeśli chodzi o wyzwanie dla tej hipotezy, zob. (Velleman 2007).

${ }^{13}$ Holton w $(2009$, 5) argumentuje, że „istnieje solidny dowód psychologiczny, że mamy intencje mniej więcej w taki sposób, jak się tu stwierdza".

${ }^{14}$ Termin ten w filozofii Bratmana nosi w zasadzie - co sugeruje sam autor - znamiona techniczności. Polskie zobowiq̨zanie - podobnie jak angielskie obligation - jest nieco obciążone semantyką moralną, której w commitment raczej nie ma. W dodatku Bratman nadaje mu specyficzne zabarwienie, które sugeruje coś więcej niż (prima facie translatorsko trafne) zaangażowanie, chodzi bowiem o zaangażowanie naznaczone 
działania, który mówi by to zrobić. Podmioty planujące są systematycznie zaangażowane $\mathrm{w}$ takie zobowiązania $\mathrm{w}$ odniesieniu do określonych planów i zobowiązania te kształtują ich myślenie praktyczne oraz działanie w czasie.

Zamierzać coś zrobić, to, jak powiedziałem, być zobowiązanym w odpowiedni sposób do planu, który mówi (być może warunkowo) by to zrobić. Próbujemy wyjaśnić tę ideę bycia odpowiednio zobowiązanym do takiego planu działania przez odwołanie się do dwóch ogólnych idei. Po pierwsze, spróbujemy scharakteryzować normalne role - normalne sposoby funkcjonowania - które są charakterystyczne dla takich stanów planowania; po drugie, spróbujemy wyartykułować podstawowe normy planowania, których przynajmniej-implicytne-zaakceptowanie przez podmiot wchodzi $w$ grę $w$ przypadku tych ról.

Zacznijmy od norm planowania. Intencje - to znaczy, stany planowania - są przedmiotem charakterystycznego kwartetu norm. Intencje mają być wewnętrznie spójne oraz spójne z przekonaniami podmiotu. Musi być możliwe skupić nasze intencje razem w pewną intencję ogólną, która jest spójna sama w sobie oraz spójna z naszymi intencjami. Ze względu na cele, intencje zakładają wymogi spójności środków i celu ukierunkowane na odpowiednie realizację naszych - normalnie tylko częściowych - planów, a także, w miarę upływu czasu - spójność ze środkami oraz krokami wstępnymi. ${ }^{15}$ Struktury stanów planowania, choć są potencjalnie obiektem rewizji, podlegają normie stabilności w czasie: istnieje pewien rodzaj rewidowalnego założenia w odniesieniu do naszych stanów planowania. W skrócie, istnieją działaniowe normy konsekwencji (consistency), skupienia (agglomeration), spójności środków i celu (means-end coherence) oraz stabilności (stability). Podmiot planujący będzie akceptował te normy przynajmniej implicytnie i będzie to sprzyjać kierowaniu myślami i działaniem podmiotu w sposób, który wspiera dostosowanie się do tych norm.

Zaakceptować te normy nie oznacza po prostu - móc się do nich dostosować. Znaczy to również - dostrzegać odstępstwa do tych norm jako niepowodzenia, a więc także - odpowiadać na takie sytuacje reakcją w rodzaju: „Do licha!". Jesteśmy przeto ukierunkowani na dostosowanie się do normy. ${ }^{16}$

To normatywne kierownictwo stanowi część wyjaśnienia charakterystycznych ról, jakie odgrywają stany planowania. Ze względu na nacisk ze strony przyjętej normy planowania by unikać niespójności

normatywnie (a więc nie będące czymś po prostu opcjonalnym). Wykorzystując uwagi Bittnera, można by commitment objaśnić jako swoiste zapisanie się na coś (np. na kurs), czy wręcz zwerbownie się do czegoś (do armii). Por. (Bittner 2001, § 97). Z braku lepszej opcji, wykorzystuję w tłumaczeniu termin zobowiq̨zanie (podobnie czyni prof. Paprzycka.)- przyp. tłum.

15 Odnotowawszy kategorię kroków wstępnych, dalej ją ignoruję i koncentruję się na środkach.

${ }^{16}$ Jeśli chodzi o dyskusję nad akceptacją normy, zob. (Gibbard 1990). Zob. także (Railton 2006). 
środków i celu, uprzednie stany planowania są źródłem problemów co do środków; podmiot będzie musiał odpowiednio zrealizować swój plan. To normalnie będzie wywoływać rozumowanie w kategoriach cel-środki, które jest ustrukturyzowane przez wcześniejsze plany cząstkowe. Ze względu na nacisk ze strony przyjętych norm planowania w odniesieniu do skupienia i konsekwencji, stany planowania będą miały tendencję do odfiltrowywania z namysłu praktycznego tych opcji intencji, które groziłyby nowymi niekonsekwencjami planu. A ze względu na nacisk ze strony przyjętej normy stabilności planu, wcześniejsza intencja zrobienia $A$ będzie miała tendencję do utrzymywania się, gdy inne warunki pozostają bez zmian (other things equal). To utrzymywanie się jest czasem wynikiem efektu kuli śniegowej: gdy raz zaczynamy działać na podstawie uprzednio obranego planu, zmieniamy świat w sposób, który wspiera dalszą kontynuację zgodnie z tymże planem. ${ }^{17}$ Czasem jest tak dlatego, że koszty zrewidowania wcześniejszych planów - i/lub ryzyka, jakie wiąże się z naruszeniem uprzednio ukutych ważnych ustaleń - są zbyt wysokie w przypadku braku uznanych powodów do zmiany; wcześniejszy plan będzie miał tendencję utrzymywać się dopóty, dopóki nie zostanie zrewidowany. ${ }^{18}$ Ale nasza działalność planowana również zakłada, jak myślę, szczególną normę stabilności, która wprost mówi, by traktować nasze wcześniejsze plany jako coś domyślnego i rewidowalnego zarazem (a defeasible default) (Bratman 2010, Bratman 2012).

Mamy więc zestaw charakterystycznych ról i związanych z nimi norm, które przynajmniej implicite akceptujemy. Taka psychologia planowania pociąga oraz wspiera złożone formy temporalnej organizacji myślenia i działania. Stan planowania w tej psychologii planowania może przemawiać za określoną opcją wbrew znanemu niedookreśleniu przez wcześniejsze powody. Gdy młody człowiek u Sartre’a wybiera plan, by współpracować z Wolną Francją, wymogi konsekwencji oraz spójności środków i celu zaczynają przybierać oraz wspierać odpowiednie formy funkcjonowania $\mathrm{w}$ ramach upływu czasu (temporally downstream functionning). Jest to prawdą mimo tego, że jego decyzja wspierania Wolnej Francji była, w jego mniemaniu, niedookreślona przez wcześniejsze powody. Podobne spostrzeżenia możemy poczynić na temat mniej dramatycznych przykładów wyboru kariery czy różnych dróg do obranego celu.

Jeśli wszystko idzie po naszej myśli, struktury planowania pociągają inter-temporalne związki referencyjne, które są zorientowane zarówno wstecz jak i w przyszłość. Mój obecny plan by w tym tygodniu pomalować dom przynajmniej implicytnie odnosi się do mojej późniejszej, zorientowanej-na-

17 Zob. (Bratman 1987, 82), gdzie odnotowuję, że etykietkę „kuli śniegowej” zawdzięczam Johnowi Etchemendy'emu.

18 Jeszcze jedno możliwe wyjaśnienie tego utrzymywania się jest takie, że często kierujemy się zwyczajami nie-refleksyjnego nie-rewidowania (non-deliberative nonreconsideration) - zwyczajami, które są dla nas generalnie użyteczne. 
dany-w-przyszłości-moment intencji (then-present-directed), by położyć ostatnią warstwę farby; i ta późniejsza intencja przynajmniej implicytnie odnosi się ponownie do mojej intencji wcześniejszej. Stabilność mojej intencji w odniesieniu do malowania $w$ tym tygodniu pomaga wesprzeć skoordynowany przepływ aktywności w czasie. Owe inter-temporalne referencyjne związki i regularności pomagają wesprzeć skuteczną, czasowo rozciągniętą strukturę częściowych planów. Te częściowe plany stanowią ogólną ramę dla dalszego namysłu na temat środków - namysłu kształtowanego przez akceptowane normy konsekwencji, spójności i skupienia.

Idea inter-temporalnie stabilnych oraz referencyjnie splatających się postaw jest znana z Locke'owskiej tradycji rozumienia tożsamości osobowej w czasie - lub, przynajmniej, tego „co ma znaczenie” dla takiej tożsamości (Parfit 1984, 217) - poprzez odwołania do nakładających się pasm ciągłości postaw oraz referencyjnych związków między postawami (Zob. Locke 1955, Ks II rozdz. 27). Standardowe funkcjonowanie stanów planowania w naszej działalności planowanej zakłada takie, w szerokim sensie Locke’owskie, więzy inter-temporalne ${ }^{19}$.

Mówiąc o akceptowanych normach planowania, dotychczas nie podjąłem kwestii tego, czy normy owe posiadają moc lub znaczenie normatywne. Dotychczas odwoływałem się jedynie do wyjaśniającej roli ich akceptacji w psychologii planowania ${ }^{20}$. Nie sądzę jednak, byśmy powinni po prostu zadowolić się taką „pozytywistyczną” teorią działalności planowanej. Są ku temu dwa powody. Pierwszy jest taki, że to my sami jesteśmy planującymi podmiotami: nasza teoria działalności planowanej jest teorią naszej działalności planowanej. Zatem, pytanie czy normy owe posiadają moc normatywną, jest tym, z którym zderzamy się w proponowaniu takiej teorii. Poza tym, istnieje prawdopodobnie, jak wiemy, wiele wzorców myślenia, które przenikają ludzką działalność, ale których - po zastanowieniu się - nie pochwalilibyśmy ${ }^{21}$. Chcemy więc wiedzieć, czy - a jeśli tak, to dlaczego - te normy planowania faktycznie spełniają standardy refleksji. Po drugie, byłby to ważny fakt teoretyczny dotyczący działalności planowanej, gdyby owe struktury działalności okazały się rzeczywiście odporne w obliczu zastanowienia nad jej elementarnymi zasadami. Jednym z ważnych sposobów ustalenia, czy nasza działalność planowana charakteryzuje się taką odpornością, jest zapytać bezpośrednio, czy te normy planowania rzeczywiście

${ }^{19}$ Chodzi tylko o to, że te więzy planowania są wśród więzów w szerokim sensie Locke'owskich, które zakładają również, w najbardziej widoczny sposób, pamięć. Można zatem przetrwać przerwę $w$ tych więzach planowania.

${ }^{20}$ Jeśli chodzi o blisko związaną dystynkcję, zob. (Schroeder 2003). Zob. też (Broome 2007).

${ }^{21}$ Zob. np. eseje w (Kahneman et al. 1982). Jeśli chodzi o dyskusję powiązanych $\mathrm{z}$ tą kwestii, zob. (Morton 2011). 
mają moc normatywną22. Pozytywna odpowiedź rozbroiłaby kwestię tego, że teoria planowania źle opisuje nasze myślenie praktyczne w takiej mierze, w jakiej przypisuje nam akceptację norm, których nie da się obronić. ${ }^{23}$

Blisko z tym spokrewniona jest sprawa czy - i w jakim sensie - te normy planowania są normami racjonalności. Możemy zacząć od obserwacji, że synchroniczne normy konsekwencji, skupienia i spójności środków i celu w planowaniu mają oczywiste paralele $\mathrm{z}$ synchronicznymi normami konsekwencji, skupienia i teoretycznej spójności przekonań; przeto istnieje również paralela między diachroniczną normą stabilności w planowaniu i diachroniczną normą zachowania przekonań (Zob. Bratman 2004a). W każdym razie, ważna paralela pozostaje. Ze względu na bliski związek z przekonaniami, wstępna sugestia radzi rozpatrywać te normy przekonań jako normy racjonalności teoretycznej dla podmiotów, które mają przekonania. Podobnie, ze względu na ich bliski związek z intencjami/planowaniem, wstępna sugestia radzi rozpatrywać normy planowania jako normy racjonalności praktycznej dla podmiotów planujących; chociaż, skoro nie wszystkie podmioty działania są podmiotami planującymi, nie muszą istnieć normy racjonalności dla wszystkich podmiotów działania ${ }^{24}$.

$\mathrm{Na}$ ten temat trzeba by powiedzieć więcej; musimy jednak najpierw powrócić do tria zdolności praktycznych, od których zacząłem ten esej.

\section{Działalność rozciągnięta w czasie}

Zdolność do rozciągniętej w czasie działalności intencjonalnej to zdolność kierowania naszymi działaniami w świetle naszego umiejscowienia w większej, rozciągniętej w czasie strukturze aktywności, do której jesteśmy praktycznie zobowiązani. Sadzimy ziarna jako część większej aktywności uprawy fasoli w naszym ogrodzie, aktywności do której jesteśmy praktycznie zobowiązani. Ta inter-temporalna organizacja aktywności jest przesiąknięta aktywnością umysłową: nie jest to po prostu inter-temporalna biologiczna organizacja ziaren jako rozwijających się w fasole.

W jakim sensie - przesiąknięta aktywnością umysłową? Moja propozycja jest taka, że dla nas, normalne wyjaśnienie tej rozciągniętej w czasie aktywności intencjonalnej zakłada plany i planowanie przez podmiot: naszym planem jest wyhodować pożywienie przez uprawę ogrodu; uznajemy, że to wymaga zaangażowania odpowiednich środków, jak posadzenie ziaren

${ }^{22}$ Twierdząc $\mathrm{w}$ ten sposób, pozostaję neutralny $\mathrm{w}$ odniesieniu do kwestii stopnia, od którego to od nas zależy, czy będziemy dalej podmiotami planującymi.

23 Jeśli chodzi o inną wersję tego zagadnienia, zob. (Kolodny 2009).

${ }^{24}$ Ta idea norm racjonalności dla szczególnego rodzaju podmiotu dobrze wpasowuje się w strategię Grice'owskiej konstrukcji istoty, która kryje się za teorią planowania. Kieran Setiya pod nagłówkiem „racjonalizmu pluralistycznego” ze sceptycyzmem odnosi się do podobnej idei (Setiya, 2014). Wiele zawdzięczam dyskusji Setiyi, choć moje konkluzje są inne. 
i nawodnienie; włączam więc te środki w plan, do którego jesteśmy praktycznie zobowiązani. Nasze praktyczne zobowiązanie do tego planu zakłada, że jesteśmy zdecydowani intencjonalnie działać w ten określony sposób ze względu na realizację całego naszego planu. $W$ ten sposób nasza rozciągnięta w czasie aktywność intencjonalna stanowi próbę naszych zdolności planowania.

Michael Thompson skrytykował to, co nazywa "skłonnością studentów filozofii praktycznej do postrzegania indywidualnych ludzkich działań jako oddzielnych, atomowych, punktowych jednostek - jakby-oka-mgnień" (Thompson 2008, 91). Myślę, że moja teoria planowania w książce z 1987 roku nie zawiniła tej rzekomej tendencji: mimo wszystko, zasadniczą sprawą tej książki było zrozumienie tego, w jaki sposób racjonalność planowania wspiera naszą działalność rozciągniętą $\mathrm{w}$ czasie. $\mathrm{W}$ obecnym kontekście chodzi o to, że pierwszy wymiar płodności działalności planowanej - wsparcie naszej zdolności do rozciągniętej w czasie działalności intencjonalnej - wpisuje się w to unikanie tendencji atomistycznej, co do którego zgadzam się z Thompsonem ${ }^{25}$.

\section{Działalność kolektywna}

Przejdźmy teraz do naszej zdolności do kolektywnej aktywności intencjonalnej. Propozycja tu jest taka, że nasza zdolność do kolektywnej aktywności intencjonalnej jest ugruntowana w naszych indywidualnych zdolnościach planowania $\mathrm{w}$ tym sensie, że ze względu na odpowiednie specjalne treści planów, kontekstów planów i wzajemnych powiązań między uczestniczącymi podmiotami planującymi, właściwe funkcjonowanie tych zdolności planowania konstytuowałoby podstawowy przypadek kolektywnej aktywności intencjonalnej.

Jak sugerowałem, nie znaczy to, że dzięki zdolności do działalności planowanej mamy tym samym zdolność do kolektywnej intencjonalności. By przejść od zdolności planowania do zdolności do intencjonalności kolektywnej, potrzebujemy kolejnych środków w postaci szczególnych treści, kontekstów i wzajemnych relacji. Pozostaje więc możliwość podmiotów planujących, które nie są zdolne do kolektywnej intencjonalności. W rzeczy samej, właśnie podobną lukę między działalnością planowaną i intencjonalnością kolektywną Michael Tomasello wraz z kolegami wskazali jako potencjalny klucz do fundamentalnej różnicy między ludźmi a innymi człowiekowatymi (Zob. Tomasello 2009). Niemniej jednak, kolejne środki pojęciowe, metafizyczne i normatywne - założone w przywołanym kroku od indywidualnej działalności planowanej do intencjonalnej działalności kolektywnej będą dostępne w ramach naszej teorii indywidualnej działalności planowanej26. Tak przynajmniej przypuszczam.

25 Thompson nie zgodziłby się jednak ze sposobem, w jaki tego atomizmu unikam.

${ }^{26}$ Jednakże, zob. kwalifikację niżej dot. „oczywistości”. 
Kluczem jest tu idea kolektywnej intencji. Gdy malujemy razem dom, razem tańczymy, gramy $\mathrm{w}$ kwartecie, razem rozmawiamy, wykonujemy eksperyment czy - jak w przykładzie Margaret Gilbert - razem spacerujemy (Gilbert 1990), nasza aktywność jest wyjaśniana przez naszą wspólną intencję działania w ten właśnie sposób. Spacerujemy razem, ponieważ my tak intendowaliśmy/zamierzyliśmy - gdzie mówienie o tym, co zamierzyliśmy zrobić oznacza mówienie o naszej kolektywnej intencji do działania w ten sposób. Taki przynajmniej związek zachodzi między aktywnością kolektywną i kolektywną intencją w przypadkach, które są w centrum naszej uwagi. Z tego względu, kolektywna aktywność intencjonalna ma swoje paralele z indywidualną aktywnością intencjonalną: w obu wypadkach, wyjaśniająca rola intencji (indywidualnej lub kolektywnej) jest fundamentalna. Chodzi więc o to, by wyartykułować struktury wewnętrznie powiązanej indywidualnej działalności planowania, której racjonalne funkcjonowanie konstytuowałoby racjonalne funkcjonowanie kolektywnej intencji.

Jeśli mamy rozpatrywać pewne przypadki wewnętrznie powiązanego racjonalnego funkcjonowania indywidualnych podmiotów planujących jako konstytuujące racjonalne funkcjonowanie kolektywnej intencji, musimy powiedzieć więcej na temat tego, czym jest owo racjonalne funkcjonowanie kolektywnej intencji. Postawmy więc te same pytania dotyczące kolektywnej intencji, które postawiliśmy w odniesieniu do intencji indywidualnej: dlaczego zajmujemy się intencjami kolektywnymi? Jakie fundamentalne role odgrywają one w naszym życiu i jakie normy się z nimi wiążą?

Moja odpowiedź na te pytania polega na podkreśleniu analogii z koordynującymi i strukturyzującymi rolami intencji oraz planów w przypadku indywidualnym a związanymi z nimi normami racjonalności indywidualnej intencji. Charakterystyczne role intencji kolektywnej, by zrobić $X$, będą zawierały interpersonalną koordynację działania i planowania $\mathrm{w}$ celu osiągnięcia $X$ oraz ustrukturyzowanie związanych z nią ustaleń i kolektywnego namysłu dotyczącego tego, jak mamy zrobić $X$. Role te będą powiązane z normami społecznej konsekwencji i skupienia, z normami społecznej spójności i stabilności. W skrócie, odpowiednie intencje powinno dać się skupić w większy plan społeczny, który jest konsekwentny, który w porę adekwatnie określa odpowiednie środki i który jest związany z odpowiednio stabilnymi psychologicznymi strukturami społecznymi. Niespełnienie tych norm społecznych normalnie będzie podkopywało szczególne role społeczne intencji kolektywnej.

Chcemy więc określić strukturę wewnętrznie powiązanych stanów planowania indywiduów (oraz innych związanych z nimi postaw tychże indywiduów) w odpowiednich kontekstach, które - jeśli funkcjonują w normatywnie określony sposób, wyróżniony przez teorię planowania indywidualnych podmiotów - odgrywają charakterystyczne dla kolektywnej intencji role po części ze względu na dostosowanie do związanych z nimi norm 
racjonalności społecznej27. To pozwoliłby nam stwierdzić, że takie indywidualistyczne struktury planowania konstytuują intencje kolektywną lub przynajmniej - pewien ważny rodzaj intencji kolektywnej.

Taką w szerokim sensie indywidualistyczną strukturę wewnętrznie powiązanych podmiotów planujących możemy nazwać konstrukcją intencji kolektywnej, a pogląd który jej broni - pewnym konstruktywizmem co do intencji kolektywnej. Nie chodzi o to, że uczestnicy sami konstruują intencję kolektywną: to my, teoretycy, dokonujemy konstrukcji ${ }^{28}$. Propozycja polega na tym, że pewna taka konstrukcja będzie konstytuować kolektywną intencję lub przynajmniej - podstawowy rodzaj intencji kolektywnej.

Taką konstrukcję próbowałem rozwinąć w innym miejscu ${ }^{29}$. Tu maluję szerokim pędzlem. Tym, czego nam trzeba, jest szereg idei wchodzących w zakres domeny naszej teorii indywidualnej działalności planowania, które zestawione razem umożliwiają nam charakterystykę zasadniczej formy kolektywnej intencji i kolektywnej aktywności intencjonalnej. W szczególności i skupiając się na kolektywnej intencji pomalowania domu, wstępne idee, których potrzebujemy, są następujące:

a) każdy z nas zamierza pomalować wspólnie dom.

b) każdy z nas zamierza pomalować wspólnie dom w zgodzie z intencją każdego innego, że pomalujemy dom ${ }^{30}$. W tym sensie nasze intencje się przeplatają.

c) każdy $\mathrm{z}$ nas zamierza pomalować wspólnie dom $\mathrm{w}$ zgodzie ze wzajemnym reagowaniem między nami w ramach sub-planu i w działaniu. W szczególności, każdy zamierza to, że nasze sub-plany zazębiają się wzajemnie, w sensie bycia współ-możliwymi, ze względu na nasze malowanie.

\footnotetext{
27 Ujmując sprawę $\mathrm{w}$ ten sposób, sygnalizuję pewną asymetrię. $\mathrm{W}$ przypadku indywidualnym, podstawowe wyjaśnienie dostosowania się do indywidualistycznych norm racjonalności zakłada przynajmniej-implicytną akceptację tych norm przez określone indywidua. W przypadku kolektywnym $\mathrm{z}$ kolei, wstępne wyjaśnienie dostosowania się do przywołanych norm społecznych odwołuje się do przynajmniejimplicytnej akceptacji norm indywidualnej racjonalności planowania przez określone indywidua. Jednakże, gdy już mamy te wzajemnie powiązane struktury planowania na pokładzie, równie dobrze może być tak, że indywidualni uczestnicy również akceptują i kierują się samymi normami społecznymi. Omawiam te kwestie w (Bratman 2014).

${ }^{28}$ Jednak w szczególnych przypadkach będzie istniał też taki sens, zgodnie z którym uczestnicy sami konstruują kolektywność (the sharing). Teoretyczna konstrukcja, którą projektuję, byłaby częścią większej Grice’owskiej strategii konstrukcji istoty.

${ }^{29}$ Zob. np. kwartet esejów na ten temat w (Bratman 1999a), (Bratman 2009c) i (Bratman 2014).

30 Myślę również, że potrzebujemy idei, iż każdy zamierza, że malujemy w zgodzie $\mathrm{z}$ intencją, że planujemy. By jednak utrzymać rzeczy w większym porządku, nie zajmuję się tu warunkiem refleksyjności.
} 
d) każdy z nas jest przekonany, że nasze intencje w a. są współzależne $\mathrm{w}$ odniesieniu do ich trwania i że ze względu na nie faktycznie pomalujemy dom.

e) faktycznie zachodzi współzależność w trwaniu intencji w a. warunki te są dla nas oczywiste.

Warunki te opisują strukturę wzajemnie powiązanych intencji każdego oraz związanych z nimi przekonań. Propozycja konstruktywistyczna jest taka, że gdy ta struktura postaw działa w zgodzie z normami teorii indywidualnej działalności planowanej, tym samym realizuje role charakterystyczne dla kolektywnej intencji po części w zgodzie ze związanymi z nimi normami racjonalności społecznej. Co więcej, gdy ta struktura faktycznie prowadzi do pomalowania domu $\mathrm{w}$ zgodzie z przywołanymi rodzajami wzajemnych reakcji, będzie miała miejsce kolektywna aktywność intencjonalna. Taka intencjonalna aktywność jest aktywnością wzajemnie powiązanych podmiotów planujących.

Bez próby pełnej obrony tej propozycji, niech mi będzie wolno poczynić tu pewien krótki komentarz. Po pierwsze, by uniknąć problemów kolistości, pojęcie naszego malowania domu, które pojawia się w treściach każdej z tych intencji, powinno (przynajmniej $\mathrm{w}$ podstawowych przypadkach) być rozumiane jako neutralne $\mathrm{w}$ odniesieniu do intencjonalności kolektywnej. Moglibyśmy malować razem w tym neutralnym sensie w przypadku, w którym każdy z nas po prostu indywidualnie maluje ten sam dom, pilnując jedynie by wzajemnie na siebie nie wpaść. (Tym, co będzie dla intencjonalności kolektywnej kluczowe, jest to, że ten neutralnie scharakteryzowany wzorzec naszych indywidualnie intencjonalnych aktywności wyjaśnia się poprzez rodzaje intencji przywołanych w konstrukcji).

Po drugie, owe warunki odwołują się do fenomenu mojej intencji, że to my działamy w pewien sposób: nie każda intencja jest intencją aby (Davis 1984) ${ }^{31}$. Sądzę, że kiedy już pojmujemy intencję w ramach teorii planowania, jest to idea zupełnie naturalna, 32 tak długo jak każdy uczestnik jest również przekonany, że jego własna intencja odpowiednio określa, czy uczestnicy zamierzają odpowiednio działać. Moje przypuszczenie jest takie, że każdy z powodzeniem może mieć takie przekonanie, gdy każdy żywi przekonanie przywołane w d. dotyczące współzależności i skuteczności 33 .

Po trzecie, warunek dotyczący przeplatania intencji wyklucza przypadki, w których każdy zamierza to, że wspólne działanie zmierza w kierunku, który nie zakłada intencji innego podmiotu, jak w przypadku pewnego mafioso, który zamierza wrzucić innego do bagażnika samochodu,

31 Choć - jak podkreślił Randolph Clarke w rozmowie - racjonalny podmiot, który zamierza to, że zrobimy $J$, normalnie będzie również zamierzał działać w odpowiedni sposób.

32 Jak zasugerował raz w rozmowie Philip Cohen.

33 Jeśli chodzi o tę ostatnią kwestię, zob. (Bratman 1999b). 
oznajmiając mu: „jedziemy razem do Nowego Orleanu”. W przeciwieństwie do przykładu z mafią, chodzi tu o to, że każdy zamierza wspólną aktywność jako przebiegającą w zgodzie z odpowiednią intencją innego uczestnika i w zgodzie ze związaną z nim wzajemną reakcją pomiędzy intencjami i działaniami uczestników. Z kolei ta zamierzona wzajemna reakcja będzie musiała zakładać zazębianie się odpowiednich sub-planów każdego z nich.

Czwarta obserwacja dotyczy warunku, że wszystko to jest oczywiste. ${ }^{34}$ Zasadniczą racją tego warunku jest to, że chcemy modelować pewien rodzaj kolektywnego rozumowania, który jest charakterystyczny dla kolektywnej intencji, to znaczy: kolektywne rozumowanie dotyczące tego, w jaki sposób realizować naszą kolektywną intencję by razem pomalować dom.

Pozostawiam sprawę otwartą, czy odpowiednia idea „tego, co oczywiste" wykracza jakoś poza pojęciowe środki naszej teorii indywidualnej działalności planowanej. Jednakże, z wyjątkiem takiej możliwej kwalifikacji, myślę że pojęciowe, metafizyczne i normatywne środki, które zaangażowaliśmy w ramach proponowanej tu konstrukcji, należą do domeny środków naszej teorii indywidualnych podmiotów planujących: konstrukcja jest pojęciowo, metafizycznie i normatywnie konserwatywna.

Zatem, podstawowe przypuszczenie jest więc takie, że współzależne i wzajemnie przeplatające się intencje każdego - ujęte razem z przywołanymi przekonaniami w publicznym kontekście - będą, w odpowiadaniu na racjonalne naciski związane $\mathrm{z}$ indywidualną działalnością planowania, funkcjonowały $\mathrm{w}$ sposób, który konstytuuje zgodne ze społecznymi normami społeczne funkcjonowanie kolektywnej intencji. A więc ta struktura współzależnych i wzajemnie przeplatających się intencji konstytuuje przynajmniej jedną zasadniczą formę kolektywnej intencji.

W ramach częściowego wsparcia dla tej podstawowej hipotezy odnotujmy, że zakładamy tu, iż każdy intenduje/zamierza wspólne malowanie w zgodzie z intencją innego, wzajemną reakcją oraz zazębiającymi się subplanami ${ }^{35}$. Oznacza to, że racjonalny nacisk na każdego, by uczynić jego własne plany spójnymi i konsekwentnymi, zapewnia racjonalne naciski na każdego, by wesprzeć sukces wspólnej aktywności oraz zazębiającej roli innego w tejże aktywności. Ze względu na moją intencję, żebyśmy pomalowali, w zgodzie z twoją intencją, wzajemną reakcją oraz zazębiającymi się sub-planami, jestem pod racjonalnym naciskiem, by się z tobą skoordynować, by wesprzeć twoją rolę

\footnotetext{
${ }^{34} \mathrm{Tu}$ jest potencjalnie na miejscu owo mówienie o wspólnej wiedzy i/lub wzajemnych przekonaniach.

${ }^{35}$ Stoi to w opozycji do przypadku, w którym każdy tylko zamierza własną aktywność, oczekując od innych jedynie wykonania ich własnej, a organizacja społeczna tych aktywności zostaje zewnętrznie wykorzystana (is out-sourced) przez pewną zewnętrzną grupę menedżerską. W takim przypadku każdy z uczestników nie będzie zobowiązany do wspólnej aktywności w sposób, który jest normalnie założony w kolektywnym namyśle dotyczącym tego, jak postępować. (Scott Shapiro omawia wersje dużej skali tego ostatniego przykładu w (Shapiro, 2014)).
} 
- być może pomagając w działaniach - i by unikać takich sposobów działania, które są z tym wszystkim niezgodne. Ze względu na twoją analogiczną intencję, ty również jesteś pod analogicznymi racjonalnymi naciskami. Te racjonalne naciski wywierane na każdego - w obliczu tych szczególnych treści i wzajemnych relacji - pociągają za sobą naciski w kierunku społecznej spójności i konsekwencji oraz związanej z nimi koordynacji oraz skuteczności - naciski, które są charakterystyczne dla kolektywnej intencjonalności.

Takie podejście do kolektywnej intencjonalności podkreśla jej pojęciową, metafizyczną i normatywną ciagłość z indywidualną działalnością planowaną. Stanowi to kontrast względem poglądów, które widzą przejście do działalności kolektywnej jako koniecznie zakładające podstawowe, nowe środki pojęciowe i/lub metafizycznie i/lub normatywne. John Searle na przykład myśli, że intencjonalność kolektywna zakłada specjalny rodzaj „myintencji” („we-intention”) w głowach indywidualnych uczestników działania. Zgodnie z poglądem Searle'a, my-intencje stanowią szczególne postawy, których nie powinniśmy utożsamiać ze zwykłymi intencjami, które dotyczą naszej indywidualnej aktywności. ${ }^{36}$ Margaret Gilbert $\mathrm{z}$ kolei uważa, że intencjonalność kolektywna zakłada pierwotny wzajemny związek „wspólnego zobowiązania” pomiędzy uczestnikami - związek, który istotowo zakłada szczególne obowiązki pozamoralne (Gilbert 2009). Nie zatrzymując się dłużej, by zbadać w szczegółach wszystkie te poglądy możemy powiedzieć, że jeśli teoretyczny model planu, który zaproponowałem, okazuje się skuteczny w określaniu warunków wystarczających dla intencjonalności kolektywnej37, to ciężar dowodu, by wyjaśnić, dlaczego również potrzebujemy tych nowych elementów pierwotnych, znajduje się po stronie Searle’a, jak i Gilbert ${ }^{38}$.

\section{Samorządność}

Przejdźmy teraz do naszej zdolności do samorządności. Moja propozycja tutaj jest taka, że klucz do nie-homunculusowego modelu naszej samorządności stanowi idea, iż pewne stany planowania zarówno dotyczą tego, co ma znaczenie $\mathrm{w}$ sensie posiadania wagi $\mathrm{w}$ namyśle praktycznym ${ }^{39}$, jak i tego, co w odpowiedni sposób wiąże razem nasze myśli i działanie - gdy działają

36 (Searle 1990). W rzeczy samej, „my-intencje” po raz pierwszy zaproponował nie Searle, a Wilfrid Sellars podczas wykładów Locke'owskich w 1966 (wydanych jako Science and Metaphysics: Variations on Kantian Themes w 1968) - przyp. tłum.

${ }^{37}$ Co z obowiązkami, które są powszechnie obecne w przykładach intencji kolektywnej i kolektywnego działania intencjonalnego? $\mathrm{Na}$ gruncie teoretycznego modelu planowania będą to znane obowiązki moralne, jak obowiązek postępowania zgodnie z wcześniejszymi zapewnieniami, lub zgodnie z zaufaniem, które zostało intencjonalnie wywołane.

38 Jak zauważył w rozmowie Michael Smith.

39 Odkładam na bok inne możliwe sensy, w jakich względy praktyczne mogą posiadać znaczenie. 
odpowiednio - tak synchronicznie, jak diachronicznie. Te podobne do planu zobowiązania do tego, co istotne (plan-like commitments to weights) przemawiają do podmiotu praktycznego, a gdy te stany planowania stanowią dlań przewodnictwo, podmiot praktyczny rządzi sobą. Ta zdolność do samorządności zakłada zdolność do kierowania myślami i działaniem przez podobne do planu zobowiązania do tego, co istotne. Nie wszystkie podmioty planujące posiadają tę ostatnią zdolność. Ten dodatek stanowi konserwatywne rozszerzenie naszego modelu działalności planowanej i jest ważnym krokiem w kierunku wskazania warunków wystarczających dla samorządności.

Do tego poglądu zaprowadziła mnie refleksja nad ideą, że w rządzeniu sobą dany praktyczny punkt widzenia podmiotu odpowiednio steruje jego myśleniem i działaniem. Taki praktyczny punkt widzenia służy za kotwicę dla namysłu, wspiera przeto ideę, że jego przewodnictwo jest formą rządzenia. I ze względu na ogólną rolę tego punktu widzenia w ekonomii psychicznej podmiotu praktycznego, jego odpowiednie przewodnictwo konstytuuje rządzenie myśleniem i działaniem podmiotu ${ }^{40}$.

Czy powinniśmy uznać, że praktyczny punkt widzenia podmiotu jest konstytuowany przez jego sądy oceniające lub normatywne? Zamierzam w tym względzie pozostać tak samo neutralny, jak w stosunku do różnych stanowisk metaetycznych, dotyczących natury tychże sądów. Założę jednak, że sądy te nie są po prostu wyrazem osobistych preferencji, ale przynależą - w pewnym sensie - do domeny tego, co intersubiektywne (Bratman 2007e, 151-154). Różne stanowiska będą interpretować na różne sposoby tę ideę. Niektóre odwołają się do idei racjonalnej zbieżności preferencji, a niektóre - do zalecania zbieżności preferencji innym. Zamierzam jednak pozostać neutralny w stosunku do tych różnic.

Po takim stwierdzeniu sądzę jednak, że istnieją problemy z proponowanym odwołaniem się do sądu oceniającego lub normatywnego. Po pierwsze, niektóre takie sądy mogą nie przynależeć do naszego punktu widzenia. Jak zauważa David Velleman, można być wyalienowanym z własnych sądów oceniających lub normatywnych (Velleman 1992, 472). Być może to właśnie powinniśmy stwierdzić w przypadku sądu Hucka Finna że powinien donieść na Jima (Bennett 19724, Arpaly, Schroeder 1999, Driver 2001, rozdz. 3). Z tym się wiąże to, że można czasem być, jak to ujął Allan Gibbard, „w uścisku” sądu oceniającego lub normatywnego (Gibbard 1990, rozdz. 4$)^{41}$. Podmioty w słynnych przykładach Milgram mogły być przekonane, że powinny zrobić to, co kazała im osoba w białym kitlu; mimo wszystko, ich bolesny konflikt wewnętrzny może wskazywać na to, że to przekonanie nie jest

40 (Bratman 2007b). To ogólne podejście - choć nie w szczegółach - jest w duchu pracy Harry'ego Frankfurta. Zob. (Frankfurt 1988a), (Frankfurt 1999a). (Ważną różnicę stanowi moje podkreślenie roli tych zobowiązań do tego, co istotne $\mathrm{w}$ namyśle praktycznym). W sprawie przewodnictwa podmiotu, zob. (Velleman 1992).

${ }^{41}$ Przykład, który wykorzystuję, pochodzi z omówienia Gibbarda. 
bezpiecznie ulokowane w ich punkcie widzenia. Co więcej, można sądzić, że coś jest dobre, lecz nie mieć $w$ stosunku do tego żadnego zainteresowania (Harman 2000b, 129). Koniec końców, jest wiele dobrych rzeczy, lecz czasu - nie aż tak wiele.

W takich przypadkach są powody, by wyłączyć pewien sąd normatywny czy oceniający z praktycznego punktu widzenia podmiotu. Istnieją również przypadki, w których istotne elementy $\mathrm{w}$ takim punkcie widzenia opierają się utożsamieniu z sądem oceniającym lub normatywnym. Pomyślmy chociażby o typach miłości, na które wskazał Harry Frankfurt (Frankfurt 2006) To, co kocham, normalnie będzie odgrywało centralną rolę w moim praktycznym punkcie widzenia. Ale w wielu przypadkach wydaje się wymuszone traktować taką miłość jako tożsamą z sądem oceniającym czy normatywnym. Co więcej, nawet jeśli staramy się odpowiedzieć na czyjeś sądy o tym, co słuszne i dobre, sądy takie mogą nie dookreślać naszych praktycznych zobowiązań. Młody człowiek u Sartre’a może traktować względy lojalności wobec swojej matki i względy lojalności wobec Wolnej Francji jako niewspółmierne, i mimo wszystko zaangażować się w zobowiązanie, które przypisuje znacząco większą wage interesom jego matki. Mogłaby go też uderzać spora niezgoda w poglądach na temat względnej wagi tych różnych form lojalności, co też - za sprawą pewnej pokory w sądzeniu - mogłoby go odwieść od intersubiektywnie wytłumaczalnego sądu oceniającego na rzecz przedkładania jednego nad drugie. Mimo wszystko, nadal mógłby ulegać zobowiązaniu, by przypisywać znacząco większą wagę raczej jednemu niż drugiemu. W każdym razie, takie zobowiązania praktyczne wykraczają poza sąd oceniający, ale nadal mogą dawać do myślenia $w$ ramach praktycznego punktu widzenia podmiotu (Bratman 2007b, 233-238).

Względy te sugerują, że centralnym elementem praktycznego punktu widzenia planującego podmiotu będą podobne do planu zobowiązania do tego, co istotne w namyśle praktycznym. Takich zobowiązań brakuje w przypadkach sądów oceniających, które są wyalienowane lub wyrażone bez zainteresowania (non-interested). W przeciwieństwie do tego, miłość zakłada podobne do planu zobowiązania do przypisywania wagi interesom ukochanej osoby. (Nie znaczy to, że zakłada tylko to.) Zobowiązania względem ideałów osobistych czy projektów zakładają podobne do planu zobowiązania do przypisywania wagi odpowiednim względom. Zobowiązania takie często będą powiązane $\mathrm{z}$ odpowiednimi sądami na temat tego, co słuszne i dobre. Niemniej jednak, nie są one $\mathrm{w}$ ogóle tożsame z lub zagwarantowane przez takie sądy, mogą więc przesądzać sprawę w odpowiedzi na niedookreślenie przez takie sądy. Rolą tych zobowiązań jest zorientowanie nas w sprawach tego, jak prowadzić własne 
życie; nie muszą one być wytłumaczalne intersubiektywnie, w sposób, który charakteryzuje sądy oceniające (Bratman 2007e, 153) ${ }^{42}$.

Co wyjaśnia, dlaczego takie podobne do planu zobowiązania przemawiają do podmiotu ${ }^{43}$ i mają taki charakter, że gdy stanowią dlań przewodnictwo, podmiot rządzi sobą? Stwierdziłem, że praktyczny punkt widzenia podmiotu służy za kotwicę namysłu praktycznego, w ten sposób przewodnictwo (guidance) sprawowane przez ten punkt widzenia jest formą rządzenia (governance). Ale napomknąłem również o innych rolach punktu widzenia - rolach, które pomagają wspierać ideę, że gdy jest on przewodnikiem, podmiot rządzi sobą. Jakie są to role?

Moja propozycja polega tu na osadzeniu roli kotwicy namysłu praktycznego w ogólnej roli spajania razem szczególnych postaci praktycznego myślenia i działania podmiotu, zarówno synchronicznie jak diachronicznie. Jakich postaci? A więc: lekcja, jaką wynieśliśmy z Locke'owskiego w szerokim sensie podejścia do tożsamości osobowej w czasie, mówi, że istnieje bliski związek między taką tożsamością - lub: tym, co w takiej tożsamości „ma znaczenie" - i nakładającymi się pasmami ciągłości postaw w różnych momentach czasu oraz wzajemne odniesienie między postawami w różnych momentach czasu. Jeśli pewne postawy, które zakotwiczają namysł praktyczny, odgrywałyby rolę spajania razem myśli i działania w ten Locke'owski w szerokim sensie sposób - w sposób, który istotowo zakłada takie diachronicznie ciągłości i wzajemne odniesienia - postawy te organizowałyby życie tego podmiotu w czasie i przeto pomagałyby ukonstytuować intertemporalną tożsamość ${ }^{44}$ podmiotu, którego życie dzięki temu charakteryzuje się taką organizacją. Moja propozycja jest taka, że to właśnie w owym odgrywaniu roli zakotwiczania namysłu w sposób, który konstytuuje i wspiera tę Locke'owską w szerokim sensie inter-temporalną organizację naszego

\footnotetext{
${ }^{42}$ Ze względu na to, że te podobne do planu zobowiązania do tego, co istotne, będą normalnie charakteryzować się odpowiednią ogólnością, nazwałem je polityką rządzenia sobą (self-governing policies); podkreśliłem również to, że będą one uwzględniały politykę dotyczącą znaczenia naszych pragnień i/lub tego, do czego owe pragnienia służą. Zob. (Bratman 2007b), (Bratman 2007c).

Istnieją ważne podobieństwa między moim odwołaniem się do polityki tego, co istotne oraz Alana Gibbarda odwołaniem się do planów "'traktowania $R$ jako przemawiającego na rzecz zrobienia $X^{\prime \prime}$ w: (Gibbard 2003, 189). Głównym punktem zainteresowania Gibbarda jest jego metaetyczna propozycja, że sądy na temat racji normatywnych są ekspresjami takich planów. Moim głównym punktem zainteresowania jest rola takich stanów planowania dla samorządności.

43 Jak się kiedyś wyraziłem - dlaczego te zobowiązania mają „podmiotowy autorytet”? Zob. (Bratman 2007d).

${ }^{44}$ Lub jakkolwiek - „co ma znaczenie” dla takiej tożsamości.
} 
myślenia i działania, dana postawa - w przypadku braku danych sytuacji konfliktowych ${ }^{45}$ - przemawia do tego podmiotu ${ }^{46}$.

Teraz chodzi o to, że podobne do planu zobowiązania do tego, co istotne faktycznie urzeczywistniają te „specyfikacje konstrukcji” („design specifications"): zakotwiczają namysł praktyczny w sposób, który zakłada te Locke'owskie $\mathrm{w}$ szerokim sensie role $\mathrm{w}$ diachronicznej organizacji praktycznego życia podmiotu. Wynika to z treści tych zobowiązań - tj., co znaczy posiadać wagę $\mathrm{w}$ namyśle praktycznym - oraz z ogólnej teorii natury stanów planowania. Ze względu na ich szczególne treści, owe podobne do planu zobowiązania mogą zapewniać przesłanki tego, co istotne - przesłanki, które kształtują namysł praktyczny. Stany planowania natomiast organizują nasze myślenie i działanie w czasie w sposób Locke’owski. Istnieje więc przykład idei, że, w przypadku danych sytuacji konfliktowych owe podobne do planu zobowiązania do tego, co istotne, faktycznie przemawiają do podmiotu. Gdy podobne do planu zobowiązania do tego, co istotne funkcjonują poprawnie, splatają razem praktyczne myślenie i działanie podmiotu w sposób, który - w przypadku braku odpowiednich sytuacji konfliktowych - pomaga ukonstytuować punkt widzenia podmiotu: ich przewodnictwo określa samorządność podmiotu.

Przypuśćmy, że mogłoby być tak, iż pewne rodzaje sądów oceniających również realizują te specyfikacje konstrukcji (Bratman 2007b, 249). Ale nie wszystkie sądy oceniające to robią; i nie tylko sądy oceniające. Istnieją systematyczne sposoby, dzięki którym sądy oceniające będą miały tendencję do niedookreślania zobowiązań praktycznych, które to robią; te zobowiązania praktyczne stanowią zaś ważne przypadki, niedające się wytłumaczyć intersubiektywnie w sposób, który charakteryzuje sąd oceniający. Jest zatem na miejscu traktować podobne do planu zobowiązania do tego, co istotne jako centralne dla naszego nie-homunculusowego modelu ludzkiej samorządności.

\section{Dlaczego racjonalność planowania ma znaczenie}

Powróćmy teraz do norm indywidualnej racjonalności planowania. Skoncentrujmy się na synchronicznych normach konsekwencji, skupienia i spójności środków i celu. Refleksja nad płodnością działalności planowanej pozwala nam tutaj powiedzieć coś na temat mocy tych norm. Mimo wszystko, akceptacja oraz bycie sterowanym przez te normy stanowią w teorii integralną część bycia podmiotem planującym. Działalność planowana jest płodna w tym sensie, że pomaga wspierać, między innymi, ważne formy działania rozciągniętego czasowo, działania kolektywnego oraz działania jako

45 To odwołanie do braku odpowiedniego konfliktu opiera się na idei Harry'ego Frankfurta dotyczącej satysfakcji, w: (Frankfurt 1999b); zob. też (Bratman 2007c, zwł. 34-35, 44).

${ }^{46}$ Powiązana idea w: (Yaffe 2000, rozdz. 3). 
samorządności. Twierdzę, że odpowiednio cenimy te formy działalności: znacząco wzbogacają nasze życie. To oznacza, że mamy dobre powody cenić bycie podmiotem planującym, jak również - cenić nasze dalsze akceptowanie tych norm. Porzucenie tych struktur planowania - gdyby było możliwe, przeszłoby lawiną przez nasze życia i byłoby kosztowne.

Jest to w szerokim sensie pragmatyczna racja przemawiająca na rzecz dalszego bycia podmiotem planującym oraz na rzecz dalszego akceptowania tych synchronicznych norm - w tym sensie „pragmatyczna”, że zakłada zarówno instrumentalne jak i nieinstrumentalne relacje między taką działalnością planowaną i tym, co odpowiednio cenimy. Owo pragmatyczne wsparcie dla dalszej akceptacji tych norm planowania zasadza się na formie rozumowania instrumentalnego, nie musi jednak w szczególności zasadzać się na spójności środków i celu w przypadku naszych intencji, spójności, która należy do norm, którym ono stara się dać wsparcie. Nie musi tu więc zachodzić błędne koło.

Mimo wszystko, pozostaje tu problem, który jest znany z zagadnienia „czczenia reguł” J.J.C. Smarta (Smart 1967). Nawet jeśli istnieją znaczące korzyści, jakie przypadają akceptacji tych ogólnych synchronicznych norm, to wydaje się, że ciągle mogą istnieć szczególne sytuacje, w których można postąpić lepiej - poprzez naruszenie jednej lub więcej tych norm. Być może istnieją, w szczególnych sytuacjach, niezwykłe korzyści płynące z niekonsekwencji i/lub niespójności. Ze względu na tę możliwość generalnie nie możemy, na podstawie wsparcia pragmatycznego dla tychże norm, wnioskować o normatywnym wsparciu na rzecz dostosowania się do nich w konkretnym przypadku ${ }^{47}$. Nadal więc pozostajemy bez wyjaśnienia normatywnej mocy tych norm w każdym konkretnym przypadku - wyjaśnienia, do którego refleksyjny podmiot planujący może się odwołać, by wesprzeć to, że dostosowuje się do tych norm w jego konkretnej sytuacji i by obalić zarzut nieuzasadnionej konsekwencji czy spójności, które „czci”.

Jedną $\mathrm{z}$ odpowiedzi na ten problem jest potraktowanie idei, że owe normy w ogóle mają w konkretnym przypadku moc normatywną, jako "mitu” (Raz 2005, Kolodny 2008). W przeciwieństwie do tego, myślę, że nasza refleksja nad relacją między działalnością planowaną oraz samorządnością wskazuje na pogląd mniej sceptyczny. Przypomnijmy, że rządzący sobą podmiot planujący będzie posiadał ustrukturyzowany planowo praktyczny punkt widzenia, który przemawia doń i którego odpowiednie przewodnictwo stanowi o jego samorządności. Zauważ, że ze względu na twój planowo ustrukturyzowany punkt widzenia, który przemawia do ciebie w konkretnej sprawie praktycznej, byłoby lepiej, gdybyś nie był w pewien sposób niekonsekwentny lub niespójny. Mimo wszystko, jeśli zamierzasz cel $C$, wiesz, że to wymaga tego, byś zamierzał podjąć środki $S$, jeśli jednak nie zamierzasz podjąć $S$, nie masz jasnego

\footnotetext{
${ }^{47}$ Nie możemy więc uwzględniać tego, co Michael Thompson nazywa „zasadą transferu tego-co-ogólne-do-tego-co-szczególne" (2008, 171).
} 
stanowiska względem $C$; nie ma, jakby mógł stwierdzić Harry Frankfurt, miejsca, gdzie mógłbyś zająć stanowisko względem $C$ (Frankfurt 1988b, 166). Sprawa ma się podobnie, jeśli zamierzasz $C$, ale również zamierzasz $D$, gdy wiesz, że $C$ i $D$ nie są współ-możliwe. W takich przypadkach mógłbyś zdołać działać intencjonalnie na podstawie określonego powodu; nie mógłbyś jednak zająć jasnego stanowiska względem $D$, którego przewodni dla twojego działania charakter może konstytuować twoją samorządność ze względu na $C$. W ten sposób naruszenie norm konsekwencji i/lub spójności wyklucza odpowiednie rządzenie sobą w przypadku podmiotów planujących takich, jak my.

Jest to uwaga $\mathrm{w}$ sprawie metafizyki samorządności $\mathrm{w}$ przypadku podmiotów planujących; nie jest ona uzależniona od tego, czy już ustaliliśmy, że dostosowanie do norm ma moc normatywną. Możemy wykorzystać tę uwagę na temat metafizyki samorządności, by wyjaśnić pewien aspekt owej mocy normatywnej. Możemy to zrobić, jeśli założymy, że istnieje dla podmiotu planującego normatywna racja, przemawiająca na rzecz jego rządzenia sobą w każdym konkretnym kontekście działalności intencjonalnej ${ }^{48}$.

Zaczynamy od uwagi - właśnie poczynionej - na temat roli konsekwencji i spójności planowania w metafizyce rządzących sobą podmiotów planujących. Wtedy odwołamy się do zasady, że jeśli istnieje normatywna racja dla $P$, by osiągnąć $C$, i jeśli $P$ ma zdolność do osiągnięcia $C$ i jeśli $X$ jest konstytutywnie konieczne dla $C$, to wówczas istnieje normatywna racja przemawiająca na rzecz $X^{49}$. Na podstawie naszego założenia na temat racji na rzecz samorządności wnioskujemy więc, że jeśli jesteś podmiotem planującym, który ma zdolność do odpowiedniej samorządności, to wtedy istnieje dla ciebie racja do rządzenia sobą, by dostosować się do norm konsekwencji i spójności planowania w tym konkretnym przypadku (Bratman 2009b) ${ }^{50}$.

By częściowo podsumować: płodność działalności planowej prowadzi do pragmatycznej racji trwania w byciu podmiotem planującym - takim, który akceptuje przywołane wyżej normy. Ze względu na to, że jesteśmy - skoro istnieją ku temu racje pragmatyczne - podmiotami planującymi, nasza samorządność zakłada, jako konieczny element konstytutywny, odpowiednią konsekwencję oraz spójność planowania. A więc, na podstawie założenia, że istnieje racja ku temu, by w konkretnym przypadku kierować naszym życiem, i że owo kierowanie sobą pozostaje w naszej mocy, istnieje racja rządzenia sobą, by w konkretnym przypadku dostosowywać się do tych synchronicznych norm - racja poza i ponad szczególnymi racjami, które przemawiają na rzecz

\footnotetext{
48 Choć może trzeba zarezerwować to przypuszczenie dla kontekstów decyzji trywialnych.

${ }^{49}$ Nie twierdzę, że termin powinien działa w ten sposób. Niemniej jednak, w związku z zaproponowaną zasadą, pojawiają się trudne kwestie, których nie mogę tu omawiać. 50 Por. myśl Davida Coppa, że „racjonalność pozostaje w służbie samorządności” (Copp $2007,351)$ oraz pogląd Kennetha Stalzera, że niespójność środków i celu stanowi defekt w „byciu wiernym sobie”. (Stalzer 2004, rozdz. 5).
} 
konkretnych, wchodzących $\mathrm{w}$ grę opcji. W tym sensie, owe zdolności do działalności planowej są samonapędzające się: jeśli faktycznie mamy te zdolności planowania (zdolności wsparte przez rację pragmatyczną) i jeśli faktycznie mamy zdolność do odpowiedniej samorządności, wówczas tym samym istnieje dla nas szczególna racja rządzenia sobą, by dostosować się w konkretnym przypadku do synchronicznych norm, których akceptacja stanowi element tych zdolności planowania ${ }^{51}$.

W ten sposób racja na rzecz samorządności, razem z metafizyką działalności planowanej jako rządzenia sobą, wspierają tendencję do ekwilibrium między naszą pragmatycznie ugruntowaną akceptacją przywołanych norm planowania oraz naszymi racjami na rzecz dostosowania się do tych norm w konkretnym przypadku. Moje orientacyjne przypuszczenie jest takie, że owo połączenie wsparcia pragmatycznego, samonapędzanie się i tendencja do normatywnego ekwilibrium użyczają kolejnego wsparcia dla idei, że te normy są faktycznie normami praktycznej racjonalności podmiotów planujących. Dzięki tym wielu sposobom płodność naszej działalności planowanej pomaga nam zrozumieć złożone znaczenie normatywne norm, których akceptacja znajduje się w sercu działalności planowanej ${ }^{52}$.

Przełożył Piotr Makowski

\section{Literatura}

Arpaly, N., Schroeder, T. 1999. "Praise, Blame and the Whole Self," Philosophical Studies 93, 161-188.

Bennett, J. 1974. "The Conscience of Huckleberry Finn," Philosophy 49, 123-134. Bratman, M. E. 1987. Intention, Plans, and Practical Reason, Cambridge, MA: Harvard UP (przedruk: CSLI Publications 1999).

—, 1999a. Faces of Intention, New York: Cambridge UP.

—, 1999b. "I Intend that We J," w: Bratman 1999a, 142-161.

—, 2007a. Structures of Agency: Essays, New York: Oxford UP.

—, 2007b. "Three Theories of Self-Governance". W: Bratman 2007a, 222-253.

—, 2007c. "Reflection, Planning, and Temporally Extended Agency". W: Bratman 2007a, 21-46.

—, 2007d. "Two Problems about Human Agency”. W: Bratman 2007a, 89-105.

51 Powiązaną ideę samonapędzania się omawiam w kontekście dyskusji poglądów Davida Gauthiera w (Bratman, 2013).

${ }^{52}$ Dziękuję uczestnikom Warsztatów na temat Działalności i Odpowiedzialności w 2011 roku w Nowym Orleanie. Specjalne podziękowania składam Davidowi Shoemakerowi zarówno za jego sprawną organizację warsztatów oraz za jego pomocne komentarze na rzecz wcześniejszego draftu. 
—, 2007e. "A Desire of One's Own”. W: Bratman 2007a, 137-161.

—, 2007f. "Valuing and the Will". W: Bratman 2007a, 47-67.

—, 2009a. "Intention, Belief, Practical, Theoretical". W: Robertson. 2009, 29-61.

—, 2009b. "Intention, Practical Rationality, and Self-Governance". Ethics 119, 411-443.

—, 2009c. "Modest Sociality and the Distinctiveness of Intention". Philosophical Studies 144, 149-165.

—, 2010. "Agency, Time, and Sociality". Proceedings and Addresses of the American Philosophical Association 84, 7-26.

—, 2012. "Time, Rationality, and Self-Governance". Philosophical Issues (Action Theory) 22, 73-88.

—, 2013. "The Interplay of Intention and Reason". Ethics 123, 657-72.

—, 2014. Shared Agency. A Planning Theory of Acting Together. New York: Oxford UP.

Broome, J. 2007. “Is Rationality Normative?". Disputatio 2, 161-78.

Cohen, P. R., Morgan, J., Pollack, M. E. eds. 1990. Intentions in Communication Cambridge, MA: MIT Press.

Copp, D. 2007. Morality in a Natural World, New York: Cambridge UP.

Davis, W. 1984. "A Causal Theory of Intending". American Philosophical Quarterly 21, 43-54.

Driver, J. 2001. Uneasy Virtue, New York: Cambridge UP.

Ferrero, L. 2009. "What Good is a Diachronic Will?". Philosophical Studies 144, 403-430.

Foot, Philippa ed. 1967. Theories of Ethics, New York: Oxford UP.

Frankfurt, H. G. 1988a. The Importance of What We Care About. New York: Cambridge UP.

Frankfurt, H. G. 1988b. "Identification and Wholeheartedness". W: Frankfurt 1988a, 159-176.

Frankfurt, H. G. 1999a. Necessity, Volition, and Love, New York: Cambridge UP.

Frankfurt, H. G. 1999b. “The Faintest Passion”. W: Frankfurt 1999a, 95-107.

Frankfurt, H. G. 2006. Taking Ourselves Seriously and Getting It Right. Stanford: Stanford UP.

Gibbard, A. 1990. Wise Choices, Apt Feelings. Cambridge, MA: Harvard UP.

Gibbard, A. 2003. Thinking How to Live. Cambridge, MA: Harvard UP.

Gilbert, M. 1990. "Walking Together: A Paradigmatic Social Phenomenon". Midwest Studies in Philosophy 15, 101-114.

Gilbert, M. 2009. "Shared Intention and Personal Intentions". Philosophical Studies 144, 167-187.

Grice, P. 1974-5. "Method in Philosophical Psychology (From the Banal to the Bizarre)". Proceedings and Addresses of the American Philosophical Association 48, 23-53. 
Harman, G. 2000a. Explaining Value and Other Essays in Moral Philosophy. New York: Oxford UP.

Harman, G. 2000b. “Desired Desires”. W: Harman 2000a, 117-136.

Holton, R. 2009. Willing, Wanting, Waiting. New York: Oxford UP.

Kahneman, D., Slovic, P., Tversky, A. eds. 1982. Judgments Under Uncertainty: Heuristics and Biases. Cambridge: Cambridge UP.

Kaufmann, W. ed. 1975. Existentialism: from Dostoevsky to Sartre. New York: Meridian/Penguin.

Kolodny, N. 2008. "The Myth of Practical Consistency". European Journal of Philosophy 16, 366-402.

Kolodny, N. 2009. "Reply to Bridges". Mind 118, 369-376.

Leist, A. ed. 2007. Action in Context. Berlin: de Gruyter/Mouton.

Locke, J. 1955. Rozważania dotyczące rozumu ludzkiego. Przeł. B. Gawecki. Warszawa: Polskie Wydawnictwo Naukowe.

Morton, J. 2011. "Towards an Ecological Theory of the Norms of Practical Deliberation". European Journal of Philosophy 19, 561-84.

Parfit, D. 1984. Reasons and Persons. New York: Oxford UP.

Railton, P. 2006. "Normative Guidance". W: Shafer-Landau, 2006, 3-33.

Raz, J. 2005. "The Myth of Instrumental Rationality”. Journal of Ethics and Social Philosophy 1, 2-28.

Robertson, S. ed. 2009. Spheres of Reason: New Essays on the Philosophy of Normativity. New York: Oxford UP.

Sartre, J. P. 1975. "Existentialism is a Humanism”. W: Kaufmann ed. 1975, 345369.

Schroeder, T. 2003. "Donald Davidson's Theory of Mind is Non-Normative". Philosophers' Imprint 3, 1-14.

Setiya, K. 2014. "Intentions, Plans, and Ethical Rationalism”. W: Vargas, Yaffe, eds. 2014, 56-82.

Searle, J. R. 1990. “Collective Intentions and Actions”. W: Cohen, Morgan, Pollack eds. 1990, 401-415.

Shafer-Landau, R. ed. 2006. Oxford Studies in Meta-Ethics 1, Oxford UP.

Shapiro, S. 2011. Legality, Cambridge: Harvard UP.

Shapiro, S. 2014. "Massively Shared Agency". W: Vargas, Yaffe eds. 2014, 258289.

Simon, H. 1983. Reason in Human Affairs. Stanford: Stanford UP.

Smart, J. J. C. 1967. “Extreme and Restricted Utilitarianism”. W: Foot ed. 1967, 171-183.

Stalzer, K. 2004. On the Normativity of the Instrumental Principle (Ph.D. Thesis, Stanford University).

Thompson, M. 2008. Life and Action. Cambridge, MA: Harvard UP.

Tomasello, M. 2009. Why We Cooperate. Cambridge, MA: MIT Press. 
Vargas, M., Yaffe, G. eds. 2014. Rational and Social Agency: The Philosophy of Michael Bratman. New York: Oxford UP.

Velleman, J. D. 1992. “What Happens When Someone Acts?”. Mind 101, 461481. Velleman, J. D. 2007. “What Good is a Will?”. W: Leist ed. 2007, 193-215.

Yaffe, G. 2000. Liberty Worth the Name: Locke on Free Agency. Princeton: Princeton UP. 
Michael E. Bratman (Stanford University, California)

\title{
The Fecundity of Planning Agency
}

\begin{abstract}
As normal adult human agents we have a remarkable trio of capacities. First, we are capable of acting over time in ways that involve important forms of intentional cross-temporal organization and coordination. Second, we are capable of acting together with others in ways that go significantly beyond standard forms of strategic interaction. Third, we are capable of self-governance. A theory of human agency should include an understanding of these capacities for temporally extended, for shared, and for self-governed intentional agency. In each case we have interrelated concerns that are conceptual, metaphysical, and normative. The response to these concerns is to seek to understand these three capacities as grounded in a common, core capacity for planning agency. This is the conjecture of the fecundity of planning agency.
\end{abstract}

Keywords: temporally extended agency, shared intentionality, self-governance, planning, intention, practical rationality

English version: "The Fecundity of Planning Agency". In: David Shoemaker (ed.). Oxford Studies in Agency and Responsibility. Oxford University Press, 4769.

Ethics in Progress (ISSN 2084-9257). Vol. 4 (2013). No. 2. pp. 87-112. 